\title{
CRITICAL LIMITS OF ZINC IN SOIL AND RICE PLANT GROWN IN ALLUVIAL SOILS OF WEST BENGAL, INDIA
}

\author{
M. K. Mahata ${ }^{1}$, P. Debnath ${ }^{2 *}$ and S. K. Ghosh ${ }^{3}$ \\ ${ }^{1}$ Assistant Director of Agriculture, Dinhata-736135, Coochbehar, West Bengal, India
}

\begin{abstract}
A study was conducted in 22 alluvial soils of West Bengal, India to estimate the critical limit of $\mathrm{Zn}$ in soil and rice plant for predicting the response of rice (Oryza sativa) to zinc application. The DTPAextractable $\mathrm{Zn}$ was positively and significantly correlated with CEC, organic carbon and clay contents and negatively correlated with $\mathrm{pH}$, silt and sand contents of soil. The DTPA-extractable $\mathrm{Zn}$ also showed a positive correlation with dry matter yield and plant $\mathrm{Zn}$ content. The critical concentration of $\mathrm{Zn}$ in these soils was established at $0.75 \mathrm{mg}$ $\mathrm{kg}^{-1}$ for rice and that of $28.0 \mathrm{mg} \mathrm{kg}{ }^{-1}$ in the plant tissue. Soil containing $\mathrm{Zn}$ below the critical limit responded appreciably to $\mathrm{Zn}$ fertilization. A negative response to $\mathrm{Zn}$ application was also observed at its higher level. The average dry matter yield increases with increasing level of $\mathrm{Zn}$ application up to $2.5 \mathrm{mg} \mathrm{kg}^{-1}$ in $\mathrm{Zn}$ deficient soils. The average response to $\mathrm{Zn}$ application in rice in $\mathrm{Zn}$ deficient soils was found to be $68.5 \%$ and $19.9 \%$ in $\mathrm{Zn}$ adequate soils.
\end{abstract}

Key words: Zinc, bray's percent yield, critical limits, alluvial soil, physico-chemical properties of soil, rice.

\section{INTRODUCTION}

Rice is one of the most important food crops and a primary food source for more than one third of world's population (Prasad et al., 2010). In Asia, India has the largest area under rice cultivation (44.3 million ha) accounting for 29.4 per cent of the global rice area. The productivity level in India is low $\left(2.04 \mathrm{t} \mathrm{ha}^{-1}\right)$ as compared to Japan (6.25t ha $\left.{ }^{-1}\right)$, China (6.24t ha $\left.{ }^{-1}\right)$ and Indonesia $\left(4.25 \mathrm{tha}^{-1}\right)$. In India, West Bengal is one of the leading states for rice cultivation. Productivity of rice depends upon balance application of nutrients. The soils of West Bengal are poor in micronutrients

\footnotetext{
${ }^{*}$ Corresponding author email: kanupran@yahoo.co.in;

${ }^{2}$ Department of Soil Science and Agricultural Chemistry, College of Horticultural and Forestry, CAU, Pasighat7991102, Arunachal Pradesh, India

${ }^{3}$ Department of Soil Science and Agricultural Chemistry, Bidhan Chandra Krishi Viswavidyalaya, Mohanpur741252, Nadia, West Bengal, India
}

Received: 04.06.2012 
due to continuous growing of high yielding varieties and only incorporation of macronutrients in cropping system. The deficiencies of micronutrients are of critical importance for sustaining high productivity of rice in India. Zinc is one of the essential plant micronutrients and its importance for crop productivity is similar to that of major nutrients (Rattan et al., 2009). Zinc plays an important role in different plant metabolism processes like development of cell wall, respiration, photosynthesis, chlorophyll formation, enzyme activity and other bio-chemical functions (Das, 2003 and Singh, 1984).

Widespread and extensive Zn deficiency has been reported in the soils of lowland rice cultivation of India, Bangladesh, Pakistan, Philippines, Myanmur, Indonesia, Japan, Korea, Taiwan and Thailand (IRRI, 1978). In West Bengal, 55\% of the soils are found to be deficient in Zn (Takkar et al., 1989). Studies on Zn fertilizer proved that the application of Zn greatly influences growth, yield and quality of rice (Patnaik et al., 2011 and Rahman et al., 2007). The symptoms of Zn deficiency have been recorded on rice and other field crops including vegetables crops grown in soils of alluvial zone of West Bengal. Realising the importance of $\mathrm{Zn}$ in plant growth and at the same time seriousness of its deficiency in soils and plants, an attempt was, therefore, made to study the critical concentration of $\mathrm{Zn}$ in soils and rice crop which is widely grown in the region of West Bengal for making $\mathrm{Zn}$ application more rational.

\section{MATERIALS AND METHODS}

Twenty two soil samples in bulk from plough layer $(0-20 \mathrm{~cm})$ were collected from different locations of alluvial zone of West Bengal. This zone comprised of four districts viz, Nadia, Burdwan, Murshidabad, and Hoogly of West Bengal, India (Table 1), lying between $22^{0} 34^{\prime}$ to $23^{0} 24^{\prime} \mathrm{N}$ latitude and $88^{0} 24^{\prime}$ to $88^{0} 33^{\prime}$ Longitude. These soils belong to order Inceptisols, Entisols and Alfisols (Soil Survey Staff, 2006). The collected soil samples were separately air dried ground and passed through $2 \mathrm{~mm}$ size sieve for laboratory analysis. Particle size distribution was done by the standard Bouyoucos hydrometer method (Gee and Bauder, 1986). Soil pH was determined by glass electrode with calomel as standard (Jakson 1973). Organic carbon was estimated by wet digestion method of Walkey and Black (Jackon, 1973). The cation exchange capacity was determined by leaching the soil with $1 \mathrm{~N}$ $\mathrm{NH}_{4}{ }^{+} \mathrm{OAC}$ and subsequently displacing the adsorbed $\mathrm{NH}_{4}{ }^{+}$methods (Gupta, 2007). Available zinc content of the soil samples was extracted with DTPA-TEA (pH 7.3) extractant following the method of Lindsay and Norvell (1978) and the concentration of $\mathrm{Zn}$ in the extracted solution was estimated with the help of Atomic Absorption Spectrophotometer (AAS).

A pot culture experiment was conducted in a greenhouse in polythene lined pots at the Instructional farm ( $22^{0} 57^{\prime} \mathrm{N}$ Latitude and $88^{\circ} 20^{\prime} \mathrm{E}$ Longitude), Mohanpur, West Bengal. The polythene lining was rinsed in $0.1 \mathrm{~N}$ HCI followed by deionized water. Four kg of each soil was transferred into each pot. Recommended doses of 
nitrogen, phosphorus and potassium @ 50, 11 and $21 \mathrm{mg} \mathrm{kg}^{-1} \mathrm{~N}, \mathrm{P}$ and $\mathrm{K}$, respectively were applied as reagent grade i.e. Urea, $\mathrm{KH}_{2} \mathrm{PO}_{4}$ and $\mathrm{KCl}$. Three 21 day old rice seedlings (var. IR 36) were transplanted in each pot. Zinc was applied @ 0, 1.25, 2.5 and $5.0 \mathrm{mg} \mathrm{kg}^{-1}$ soil as reagent grade of Zinc sulphate $\left(\mathrm{ZnSO}_{4}, 7 \mathrm{H}_{2} \mathrm{O}\right)$ after 7 days of transplanting of rice seedling. Each treatment was replicated thrice in completely randomized design. Watering with deionized water and intercultural operations like weed control and plant protection measures were adopted uniformly in each pot as and when required. Rice plants of above ground portion were harvested after 30 days of transplanting and washed in acidified solution, rinsed with deionized water, dried at $65{ }^{\circ} \mathrm{C}$ in a hot air oven and dry-matter yield was recorded. The dried rice plant and dried $3^{\text {rd }}$ leaf samples of each pot were separately powdered in a warring stainless steel grinder. The dry powdered plant samples were digested in a mixture of 10:4:1 of $\mathrm{HNO}_{3}: \mathrm{HClO}_{4}: \mathrm{H}_{2} \mathrm{SO}_{4}$ on a hot plate and filtered through Whatman No.42 for estimation of $\mathrm{Zn}$ with the help of Atomic Absorption Spectrophotometer (AAS). The critical value of DTPA-extracted zinc in soil and in plant were determined by plotting the Bray's percent yield against soil DTPAextracted zinc content and separately against plant tissue zinc content respectively, following the method of Cate and Nelson (1965).

$$
\text { Bray's percent Yield }=\frac{\text { Yield without } Z n \text { treatment }}{\text { Yield at optimum Zn tretment }} \quad \mathrm{x} 100
$$

Simple correlation analysis was carried out to establish the relationships between the $\mathrm{Zn}$ and soil properties.

\section{RESULTS AND DISCUSSION}

\section{Soils properties}

The data of DTPA-extracted zinc and relevant physical and chemical properties of the soils of alluvial zone of West Bengal are presented in table 1. From data it was seen that soil texture varied from sandy to clay. The soils had $\mathrm{pH}$ values ranging from 5.6 to 7.5 with a mean value of 6.5 . Soils were slightly acidic to neutral in reactions. The organic carbon status of soil samples ranged from 4.5 to $9.5 \mathrm{~g} \mathrm{~kg}^{-1}$ with a mean value of $6.5 \mathrm{~g} \mathrm{~kg}^{-1}$. In general, soils were low in organic carbon content and more than 60 per cent soils were found to be low in organic carbon. The range of

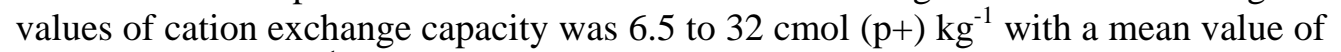
$15.81 \mathrm{cmol}\left(\mathrm{p}^{+}\right) \mathrm{kg}^{-1}$. The results are in agreement with earlier works of Debnath et al., (2009) and Thakur et al., (2011).

\section{Critical limits of zinc in soils and third leaf rice plant}

The available $\mathrm{Zn}$ content ranged from 0.60 to $0.97 \mathrm{mg} \mathrm{kg}^{-1}$ with a mean value of $0.79 \mathrm{mg} \mathrm{kg}^{-1}$ (Table 1). The percent of dry matter yield of rice ranged between 53.2- 104.9 with a mean value of 74.9. The value of $\mathrm{Zn}$ concentration in $3^{\text {rd }}$ leaf of 
rice crop, total $\mathrm{Zn}$ in entire shoot and $\mathrm{Zn}$ uptake by rice shoot in no $\mathrm{Zn}$ applied pots were 15.1-39 mg kg-1, 20- $45 \mathrm{mg} \mathrm{kg}^{-1}$ and 108- $661.5 \mu \mathrm{g} \mathrm{pot}^{-1}$ with respective mean value of $24.5 \mathrm{mg} \mathrm{kg}^{-1}, 32.1 \mathrm{mg} \mathrm{kg}^{-1}$ and $329.2 \mu \mathrm{g} \mathrm{pot}^{-1}$ (Table 2). The plot of Bray's per cent yield against soil available $\mathrm{Zn}$ and plant tissue $\mathrm{Zn}$ revealed 0.75 and $28.0 \mathrm{mg}$ $\mathrm{kg}^{-1}$, respectively as the critical concentration of $\mathrm{Zn}$ in soils and plant (Figure 1 \& 2). These values are close to critical level of $\mathrm{Zn}\left(0.83 \mathrm{mg} \mathrm{kg}^{-1}\right)$ as observed by Rahman et al., (2007), Muthukumararaja et al., (2012) and Gangwar and Chandra (1975). However, critical limit of DTPA-extracted $\mathrm{Zn}$ and plant tissue $\mathrm{Zn}$ was $0.76 \mathrm{mg} \mathrm{kg}^{-1}$ soil and $21.5 \mathrm{mg} \mathrm{kg}^{-1}$ reported by Sakal et al., (1984) for rice in Sub-Himalayan hill and forest soils of India, below which appreciable responses to $\mathrm{Zn}$ application were observed. Based on the soil test, plant analysis and response of different crops to the application of $\mathrm{Zn}$ in greenhouse and field trial, the critical limit of $\mathrm{Zn}$ of $0.60 \mathrm{~g} \mathrm{~kg}$ ${ }^{1}$ (DTPA-extracted) for rice and wheat has so far been fixed for West Bengal (Das and Saha, 1999).

\section{Effect of zinc on dry matter yield}

The data presented in table 3 revealed that the average response in dry matter yield (\%) at optimum level of applied $\mathrm{Zn}$ in soils below critical limit ranged from 51.2 to 89.6 per cent with mean value of 68.5 per cent. With increasing the level of $\mathrm{Zn}$ content in soil above the critical limit, the percentage responses also decreased which varied from (-) 5.2 to 70.3 per cent with a mean value of 19.9 per cent. On the other hand, the application of $\mathrm{Zn}$ increased the average shoot yield from 8.4 to 11.76 $\mathrm{g} \mathrm{pot}^{-1}$ up to $5.0 \mathrm{mg} \mathrm{Zn} \mathrm{kg}^{-1}$ soil below the critical value (Patnaik and Bhupal, 2001). The positive effect of $\mathrm{Zn}$ might be due to its beneficial effect on metabolism (Rashid and Fox 1992). Whereas, above the critical value, the application of Zn fertilizer increased the average shoot yield marginally from 11.38 to $13.04 \mathrm{~g} \mathrm{pot}^{-1}$ up to $2.5 \mathrm{mg}$ $\mathrm{Zn} \mathrm{kg}^{-1}$ soil. However, a substantial amount of average dry matter yield decreased with increasing levels of applied zinc fertilizer in the soils containing $\mathrm{Zn}$ above critical limit up to $5.0 \mathrm{mg} \mathrm{Zn} \mathrm{kg}^{-1}$ soil. The decrease in dry matter yield at higher $\mathrm{Zn}$ levels may be ascribed to Zn toxicity in plant tissue (Singh, 1984). Based on critical value of available $\mathrm{Zn}$, soils were grouped into deficient and adequate classes (Table 3). Considering critical value of $\mathrm{Zn}$ in soils $\left(0.75 \mathrm{mg} \mathrm{kg}^{-1}\right), 13$ soils were rated to be adequate and $53.8 \%$ soils belonging to this category responding to $\mathrm{Zn}$ application. Whereas, $100 \%$ soils below the critical value showed the positive response to $\mathrm{Zn}$ application and number of soils in this category were nine (9). However, closer examination indicated that the magnitude of mean percentage response due to $2.5 \mathrm{mg}$ $\mathrm{kg}^{-1}$ level of Zn application over $0 \mathrm{mg} \mathrm{kg}^{-1}$ was found to be maximum (Table 2). This indicated that Zn can be applied for rice @2.5 mg kg-1 in the soils of alluvial zone of West Bengal, where the Zn content was below $0.75 \mathrm{mg} \mathrm{kg}^{-1}$. Naik and Das (2010) reported that the application of zinc as Zn-EDTA @ $1 \mathrm{~kg} \mathrm{ha}^{-1}$ to low land rice soil of West Bengal resulted the $37.8 \%$ and $20.9 \%$ greatest increase in grain and straw yield of rice respectively, over the control. 


\section{Correlation among soil properties and zinc}

The DTPA- extracted Zn exhibit significant positive correlation with organic carbon $\left(\mathrm{r}=0.63^{* *}\right)$, Clay $\left(\mathrm{r}=0.62^{* *}\right)$, CEC $\left(\mathrm{r}=0.71^{* *}\right)$, and Bray's percentage yield $\left(r=0.77^{*}\right)$ of the soils (Table 4$)$, whereas, a negative relationship was also observed between $\mathrm{pH}(\mathrm{r}=-0.11)$, silt $\left(\mathrm{r}=-0.47^{*}\right)$ and sand $(\mathrm{r}=-0.04)$. Such behaviour was also reported by Yadav and Meena (2009) and Thakur et al., (2011). This suggests that organic matter, clay and CEC are the major factors of determining the Zn availability in soils. Further, Bray's percentage yield have significant and positive association with $\mathrm{Zn}$ concentration in plant tissues of $3^{\text {rd }}$ leaf and $\left(\mathrm{r}=0.97^{* *}\right)$ and total $\mathrm{Zn}$ concentration in plant tissues $\left(\mathrm{r}=0.97^{* *}\right)$. Similar correlation was also reported by Rahman et al., (2007).

\section{CONCLUSION}

The results indicate that the critical limit values of DTPA-extracted Zn in soil and third leaf of the rice plants were 0.75 and $28.0 \mathrm{mg} \mathrm{kg}^{-1}$, respectively. It is evident from the study that Zn @ $2.5 \mathrm{mg} \mathrm{kg}^{-1}$ needs to be applied to obtain optimum yield for rice in the soils of alluvial zone of West Bengal. The soils will likely respond to $\mathrm{Zn}$ application more when it contains less than $0.75 \mathrm{mg} \mathrm{kg}^{-1}$ DTPA- extracted Zn.

\section{REFERENCES}

Cate, R.B. and Nelson, L,A. 1965. A rapid method for correlation of soil test analysis with plant response data. International Soil Test Series Technology Bulletin. No.1.North Carolina State University Agricultural Experiment Station, Raleigh.

Das, D.K. 2003. Micronutrients: Their Behavior in Soils and Plants, Kalyani Publishers,New Delhi.

Das, D.K. and Saha, D. 1999. Boron. In Micronutrient Research in Soils and Crops of West Bengal, Silver Jubilee Commemoration; Department of Agricultural Chemistry and Soil Science. Bidhan Chandra Krishi Viswavidyalaya, Mohanpur, Nadia, West Bengal.

Debnath, P., Chandra, G. and Ghosh, S.K. 2009. Critical limit of available boron for rice under Red and Lateriate zone of West Bengal, India. SAARC J. Agril., 7: 99-105.

Gangwar, M.S. and Chandra, S.K. 1975. Estimation of critical limit for zinc in rice soils. Communi. Soil. Sci. and Pl. Anal., 6: 641-654.

Gee, G.W. and Bauder, J.W. 1986. Particle size analysis in Methods of Soil Analysis, $2^{\text {nd }}$ Edition, Part-I - Physical and Mineralogical Methods,(Edited by A. Klute), American Society of Agronomy, Inc., Madison, Wisconsin, USA.

Gupta, P.K. 2007. Soil, Plant, Water and Fertilizer Analysis, Agrobios, Jodhpur, India.

IRRI. 1978. Annual report for 1977, Los Banos, Philippines, 21-24.

Jackson, M.L. 1973. Soil Chemical Analysis. Prientice Hall of India Pvt. Ltd. New Delhi.

Lindsay, W.L. and Norvell, W.A. 1978. Development of DTPA soil test for Zn, Fe, Mn and Cu. Soil Sci. Soci. American J., 42: 421-428. 
Muthukumararaja,T. and Sriramachandrasekharan, M.V. 2012. Critical limit of zinc for rice soils of Veeranam command area, Tamil Nadu, India. ARPN J. Agril. and Bio. Sci., 7: 22-33

Naik, S.K. and Das, D.K. 2010. Evaluation of various zinc extractants in low land rice soil under the influence of zinc sulphate and chealated zinc. Communi. Soil. Sci. and Pl. Anal., 41: 122-134.

Patnaik, M.C., Raju, A.C. and Bhupal, R, G. 2011. Zinc requirement of hybrid rice -Bhendi and its influence on zinc fractions in an Alfisol of Hyderabad, Andhra Pradesh. $J$. Indian Soc. Soil Sci., 9: 368-375.

Patnaik, M.C. and Bhupal, R.G. 2001. Direct, residual and cumulative effect of zinc in ricerice cropping system. Oryza., 36: 331-334.

Prasad, R., Prasad, L.C. and Agrawal, R.K. 2010. Genetic diversity in Indian germplasm of aromatic rice. Oryza., 46: 197-201.

Rahman, M.A., Jahiruddin, M. and Islam, M.R. 2007. Critical limit of zinc for rice in calcareous soils. J. of Agric. Rural Dev., 5: 47-47.

Rashid, A. and Fox, R.L. 1992. Evaluating internal zinc requirements of grain crops by seed analysis. J. Agron., 84: 469-474.

Rattan, R.K., Patel, K.P., Manjaiah, K.M. and Datta, S.P. 2009. Micronutrients in soil, plant animal and human health. J. Indian Soc. Soil Sci., 57: 546-558.

Sakal, R., Singh, A.P., Singh, B.P. and Sinha, R.B. 1984. Assessment of some chemical extractants for available zinc in relation to response of rice to applied zinc in SubHimalayan Hill and forest soils. Plant and Soil., 79: 417-428.

Singh, K. 1984. Determination of critical limit of zinc in rice soils in India for predicting response of rice to zinc application. Field Crops Res., 9: 143-149.

Soil Survey Staff. 2006. Keys to Soil Taxonomy, $10^{\text {th }}$ edition, United States Department of Agriculture, NRCS, Washington, D.C., USA.

Takkar, P.N., Chibba, I.M. and Mehta, S.K. 1989. Twenty Years of Coordinated Research on Micronutrients in Soils and Plants. Indian Institute of Soil Science. Bhopal. ICAR Publication.

Thakur, R., Kauraw, D. L. and Singh, M. 2011. Profile distribution of micronutrient cation in a Vertisols as influenced by long term application of manure and fertilizer $J$. Indian Soc. Soil Sci., 59: 239-244.

Yadav, R.L. and Meena, M.C. 2009. Available micronutrients status and their relationship with soil properties of Degana soil series of Rajasthan. J. Indian Soc. Soil Sci., 57: 90-92. 
CRITICAL LIMITS OF ZINC IN SOIL

Table 1. Soil properties and DTPA-extractable zinc in experimental soils.

\begin{tabular}{|c|c|c|c|c|c|c|c|c|c|c|}
\hline \multicolumn{2}{|c|}{ Locations/Districts } & \multicolumn{7}{|c|}{ Physico-chemical properties of soils } & \multirow{4}{*}{\begin{tabular}{|c|}
$\begin{array}{c}\text { DTPA- } \\
\text { extractable } \\
\text { zinc } \\
\left(\mathbf{m g ~ k g}^{-1}\right)\end{array}$ \\
0.60 \\
\end{tabular}} & \multirow{4}{*}{\begin{tabular}{|l} 
Soil Order \\
Alfisols \\
\end{tabular}} \\
\hline \multirow{2}{*}{\multicolumn{2}{|c|}{ Nadia }} & \multirow{3}{*}{$\begin{array}{c}\mathbf{p H} \\
\\
6 \\
\end{array}$} & \multirow{3}{*}{$\begin{array}{c}\begin{array}{c}\text { Organic } \\
\text { carbon } \\
\left(\mathbf{g ~ k g}^{-1}\right)\end{array} \\
4.5 \\
\end{array}$} & \multirow{2}{*}{ Sand } & \multirow{3}{*}{$\begin{array}{l}\text { Silt } \\
\% \\
\end{array}$} & \multirow{3}{*}{\begin{tabular}{|c|} 
Clay \\
13.3 \\
\end{tabular}} & \multirow{3}{*}{\begin{tabular}{|c|}
$\begin{array}{c}\text { Textural } \\
\text { Classes }\end{array}$ \\
sil \\
\end{tabular}} & \multirow{3}{*}{$\begin{array}{c}\begin{array}{c}\text { CEC } \\
\text { C mol } \\
\left(\mathbf{p}^{+}\right) \mathbf{k g}^{-1}\end{array} \\
6.5 \\
\end{array}$} & & \\
\hline & & & & & & & & & & \\
\hline 1 & Kaligunj & & & 18.7 & & & & & & \\
\hline 2 & Debogram & 7.3 & 6.7 & 30.8 & 46 & 23.2 & l & 8.6 & 0.68 & Inceptisols \\
\hline 3 & Nakashipara & 6.8 & 5.0 & 24.2 & 54.6 & 21.2 & sil & 8.5 & 0.63 & Entisols \\
\hline 4 & Dhubulia & 7.1 & 4.7 & 19 & 62 & 19 & sil & 8.5 & 0.60 & Inceptisols \\
\hline 5 & Ranaghat & 6.7 & 6.2 & 14.2 & 50.8 & 35 & sicl & 19.2 & 0.86 & Inceptisols \\
\hline 6 & Chakdah & 7 & 8.9 & 12 & 42.4 & 45.6 & sic & 20.9 & 0.92 & Entisols \\
\hline \multicolumn{2}{|c|}{ Burdwan } & & & & & & & & & \\
\hline 7 & Konarpara & 5.8 & 6.7 & 25.8 & 44.2 & 30 & 1 & 12.5 & 0.70 & Alfisols \\
\hline 8 & Balidanga & 6.2 & 5.0 & 48.4 & 26 & 25.6 & 1 & 12.2 & 0.73 & Entisols \\
\hline 9 & Srirampur & 6.5 & 5.5 & 29.2 & 30 & 40.8 & $\mathrm{c}$ & 16.4 & 0.70 & Inceptisols \\
\hline 10 & Mirzaqpur & 6.5 & 8.3 & 30.2 & 35 & 34.8 & $\mathrm{cl}$ & 18 & 0.96 & Inceptisols \\
\hline 11 & Hangram & 6.2 & 7.2 & 25.4 & 44.6 & 30 & $\mathrm{cl}$ & 16.4 & 0.82 & Inceptisols \\
\hline 12 & Totpara & 5.6 & 7.6 & 43.4 & 20 & 36.6 & c & 18.4 & 0.94 & Alfisols \\
\hline 13 & Banpara & 6.1 & 6.6 & 35.6 & 42.1 & 22.3 & 1 & 14.8 & 0.86 & Inceptisols \\
\hline 14 & Ghoghat & 6 & 4.7 & 47 & 25 & 28 & sc & 18.1 & 0.74 & Entisols \\
\hline 15 & $\begin{array}{c}\text { Shyam } \\
\text { sundarpur }\end{array}$ & 6.2 & 7.8 & 30 & 35.1 & 34.9 & $\mathrm{cl}$ & 14.1 & 0.95 & Entisols \\
\hline \multicolumn{2}{|c|}{ Murshidabad } & & & & & & & & & \\
\hline 16 & Sagardihi & 6.2 & 5.3 & 22 & 37.1 & 40.9 & c & 19.9 & 0.82 & Alfisols \\
\hline 17 & Nabagram & 6.6 & 5.5 & 10 & 41 & 49 & c & 32 & 0.94 & Entisols \\
\hline 18 & Surjyapur & 7.2 & 9.0 & 30.6 & 50.8 & 18.6 & sil & 12.6 & 0.80 & Inceptisols \\
\hline 19 & Gura & 7.5 & 9.5 & 12 & 46.3 & 41.7 & sic & 20 & 0.97 & Inceptisols \\
\hline \multicolumn{2}{|c|}{ Hooghly } & & & & & & & & & \\
\hline 20 & Tarakeshwar & 6.5 & 7.6 & 10.9 & 48.3 & 40.8 & sic & 18.2 & 0.78 & Inceptisols \\
\hline 21 & Balagarh & 6.7 & 5.4 & 21.4 & 47 & 31.6 & 1 & 16.4 & 0.83 & Entisols \\
\hline 22 & Kanagar & 6.7 & 6.8 & 12.3 & 52.1 & 35.6 & $\mathrm{c}$ & 15.6 & 0.65 & Entisols \\
\hline \multicolumn{2}{|c|}{ Range value } & 5.6-7.5 & $4.5-9.5$ & $10-48.4$ & $20-68$ & $13.2-49$ & & $6.5-32$ & $0.60-0.97$ & \\
\hline \multicolumn{2}{|r|}{ Mean } & 6.5 & 6.5 & 25 & 43 & 32 & & 15.81 & 0.79 & \\
\hline
\end{tabular}

cl= clay loam, l=Loam, sil=silt loam, siclL=silty clay loam, sic=silty clay, c=clay, sc=sandy clay 
Table 2. Effect of Zn application on dry-matter yield, Zn concentration in leaf and shoots and Zn uptake by rice.

\begin{tabular}{|c|c|c|c|c|c|c|c|c|}
\hline \multirow[t]{3}{*}{ Sl No } & \multicolumn{4}{|c|}{ Shoot weight $\left(\mathrm{g} \mathrm{pot}^{-1}\right)$} & \multirow{3}{*}{$\begin{array}{c}\text { Percent dry } \\
\text { matter yield } \\
\text { at optimum } \\
\text { Zn level }\end{array}$} & \multirow{3}{*}{\begin{tabular}{|} 
Total Zn in the \\
$3^{\text {rd leaves of }}$ \\
rice plants at \\
no Zn pots (mg \\
$\mathrm{kg}^{-1}$ )
\end{tabular}} & \multirow{3}{*}{\begin{tabular}{|c|} 
Total $\mathrm{Zn}$ in \\
rice shoots \\
at no $\mathrm{Zn}$ \\
pots (mg \\
$\left.\mathrm{kg}^{-1}\right)$
\end{tabular}} & \multirow{3}{*}{$\begin{array}{c}\text { Zn uptake by } \\
\text { rice shoots ( } \mu \text { g } \\
\left.\text { pot }^{-1}\right) \text { in no Zn } \\
\text { pots }\end{array}$} \\
\hline & \multicolumn{4}{|c|}{ Application of Zn (mg kg soil) } & & & & \\
\hline & 0 & 1.25 & 2.50 & 5 & & & & \\
\hline 1 & 6.1 & 8.2 & 9.5 & 10.6 & 57.6 & 15.8 & 22.0 & 134.2 \\
\hline 2 & 6.9 & 8.9 & 10.5 & 11.8 & 57.8 & 17.5 & 26.0 & 179.4 \\
\hline 3 & 5.8 & 8.0 & 9.7 & 11.0 & 53.2 & 16.3 & 24.0 & 139.2 \\
\hline 4 & 6.5 & 8.4 & 9.7 & 11.3 & 58.2 & 16.0 & 24.0 & 156 \\
\hline 5 & 12.4 & 13.5 & 13.0 & 12.2 & 91.8 & 33.0 & 40.0 & 496 \\
\hline 6 & 8.9 & 11.5 & 12.7 & 12.4 & 70.2 & 21.0 & 29.0 & 258 \\
\hline 7 & 7.2 & 9.0 & 10.9 & 11.7 & 61.4 & 16.5 & 26.0 & 187.2 \\
\hline 8 & 7.5 & 10.1 & 11.7 & 12.4 & 60.5 & 20.0 & 28.0 & 210 \\
\hline 9 & 7.9 & 9.5 & 11.5 & 12.0 & 66.2 & 20.5 & 26.0 & 205.4 \\
\hline 10 & 14.7 & 14.5 & 13.8 & 13.0 & 102 & 39.0 & 45.0 & 661.5 \\
\hline 11 & 12.4 & 13.2 & 14.5 & 13.4 & 85.5 & 28.5 & 37.0 & 458.8 \\
\hline 12 & 13.5 & 12.8 & 12.7 & 12.2 & 104.9 & 37.0 & 43.0 & 580.5 \\
\hline 13 & 11.9 & 12.7 & 12.6 & 12.3 & 94 & 37.0 & 43.0 & 511.7 \\
\hline 14 & 8.2 & 10.5 & 12.2 & 12.4 & 65.4 & 19.5 & 27.5 & 225.5 \\
\hline 15 & 13.8 & 13.6 & 13.4 & 12.4 & 101.9 & 38.0 & 45.0 & 621 \\
\hline 16 & 11.5 & 13.1 & 14.2 & 13.1 & 81.6 & 25.6 & 35.0 & 402.5 \\
\hline 17 & 12.6 & 13.7 & 13.5 & 13.0 & 92 & 35.0 & 42.0 & 529.2 \\
\hline 18 & 10.5 & 12.4 & 13.0 & 12.2 & 80.6 & 23.0 & 33.0 & 346.5 \\
\hline 19 & 5.4 & 7.1 & 8.8 & 9.2 & 58.8 & 15.5 & 20.0 & 108 \\
\hline 20 & 9.5 & 11.7 & 13.2 & 12.3 & 72.5 & 22.0 & 32.0 & 304 \\
\hline 21 & 10.9 & 13.0 & 14.2 & 12.0 & 76.5 & 23.5 & 33.0 & 359.7 \\
\hline 22 & 6.4 & 8.5 & 10.1 & 11.4 & 55.5 & 18.0 & 26.0 & 166.4 \\
\hline Range value & $5.4-14.7$ & 7.1-14.5 & 8.8-14.5 & $9.2-13.4$ & 53.2-104.9 & 15.1-39 & $20-45$ & $108-661.5$ \\
\hline Mean & 9.5 & 11.1 & 12.1 & 12.0 & 74.9 & 24.5 & 32.1 & 329.2 \\
\hline
\end{tabular}


Table 3. Response of rice crop to $\mathrm{Zn}$ application.

\begin{tabular}{|c|c|c|c|c|c|c|c|c|}
\hline \multirow[t]{3}{*}{$\begin{array}{l}\text { DTPA-extractable } \\
\left.\text { Zn (mg kg }{ }^{-1}\right)\end{array}$} & \multirow[t]{3}{*}{$\begin{array}{l}\text { No. of } \\
\text { soils }\end{array}$} & \multirow[t]{3}{*}{$\begin{array}{l}\text { Percentage } \\
\text { of } \\
\text { responding } \\
\text { soils }\end{array}$} & \multirow{2}{*}{\multicolumn{4}{|c|}{ Average dry matter yield $\left(\mathrm{g} \mathrm{pot}^{-1}\right)$}} & \multicolumn{2}{|c|}{$\begin{array}{c}\text { Average response in } \\
\text { dry matter yield (\%) } \\
\text { at optimum level of } \\
\text { applied Zn }\end{array}$} \\
\hline & & & & & & & \multirow[t]{2}{*}{ Range } & \multirow[t]{2}{*}{ Mean } \\
\hline & & & 0 & 1.25 & 2.5 & 5.0 & & \\
\hline$<0.82$ (Deficient) & 9 & 100 & 8.4 & 9.96 & 11.1 & 11.76 & $51.2-89.6$ & 68.5 \\
\hline$>0.82$ (Adequate) & 13 & 53.8 & 11.38 & 12.52 & 13.04 & 12.28 & $(-) 5.2-70.3$ & 19.9 \\
\hline
\end{tabular}

A soil was classified as responsive to $\mathrm{Zn}$ where the per cent response was more than 10 .

Table 4. Correlation coefficient (r-values) between DTPA-extractable Zn and soil properties

\begin{tabular}{|c|l|l|}
\hline Sl. no. & \multicolumn{1}{|c|}{ Variables } & r- value \\
\hline 1 & Soil pH vs DTPA-extractable Zn & -0.11 \\
\hline 2 & Organic carbon vs DTPA-extractable Zn & $0.63^{* *}$ \\
\hline 3 & Clay vs DTPA-extractable Zn & $0.62^{* *}$ \\
\hline 4 & Silt vs DTPA-extractable Zn & $-0.47^{*}$ \\
\hline 5 & Sand vs DTPA-extractable Zn & -0.04 \\
\hline 6 & CEC vs DTPA-extractable Zn & $0.71^{* *}$ \\
\hline 7 & Bray's percentage yield vs DTPA-extractable Zn & $0.77^{* *}$ \\
\hline 8 & Zn concentration in 3 ${ }^{\text {rd }}$ leaves vs DTPA-extractable Zn & $0.69^{* *}$ \\
\hline 9 & $\begin{array}{l}\text { Bray's percent yield and Zn concentration in plant tissues of } 3^{\text {rd }} \\
\text { leaves }\end{array}$ & $0.97^{* *}$ \\
\hline 10 & Bray's percent yield and total Zn concentration in plant tissues & $0.97^{* *}$ \\
\hline
\end{tabular}

$* * \leftarrow 1 \%$ level of significant, $\quad * \leftarrow 5 \%$ level of significant 


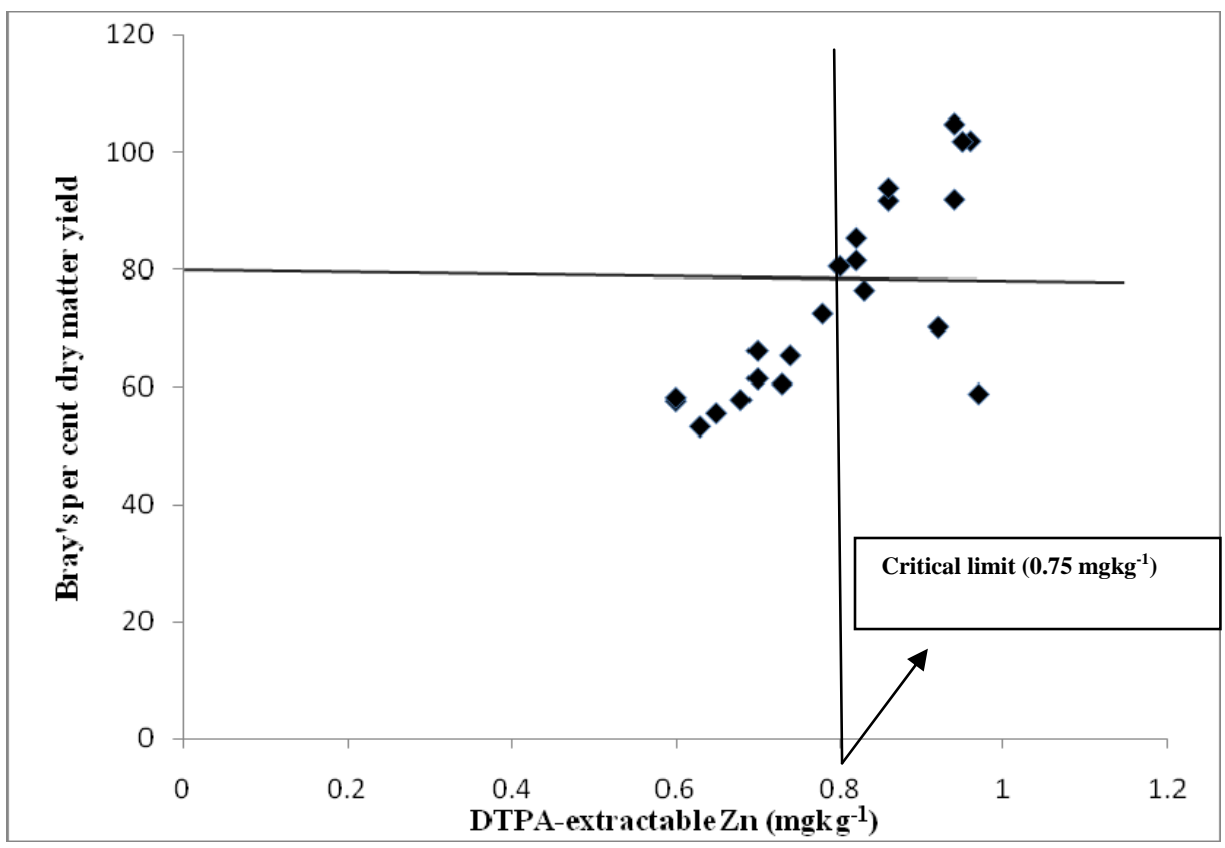

Figure 1. Scatter diagram of DTPA-extractable Zn Vs. percent dry matter yield of rice grown in soils of alluvial zone of West Bengal.

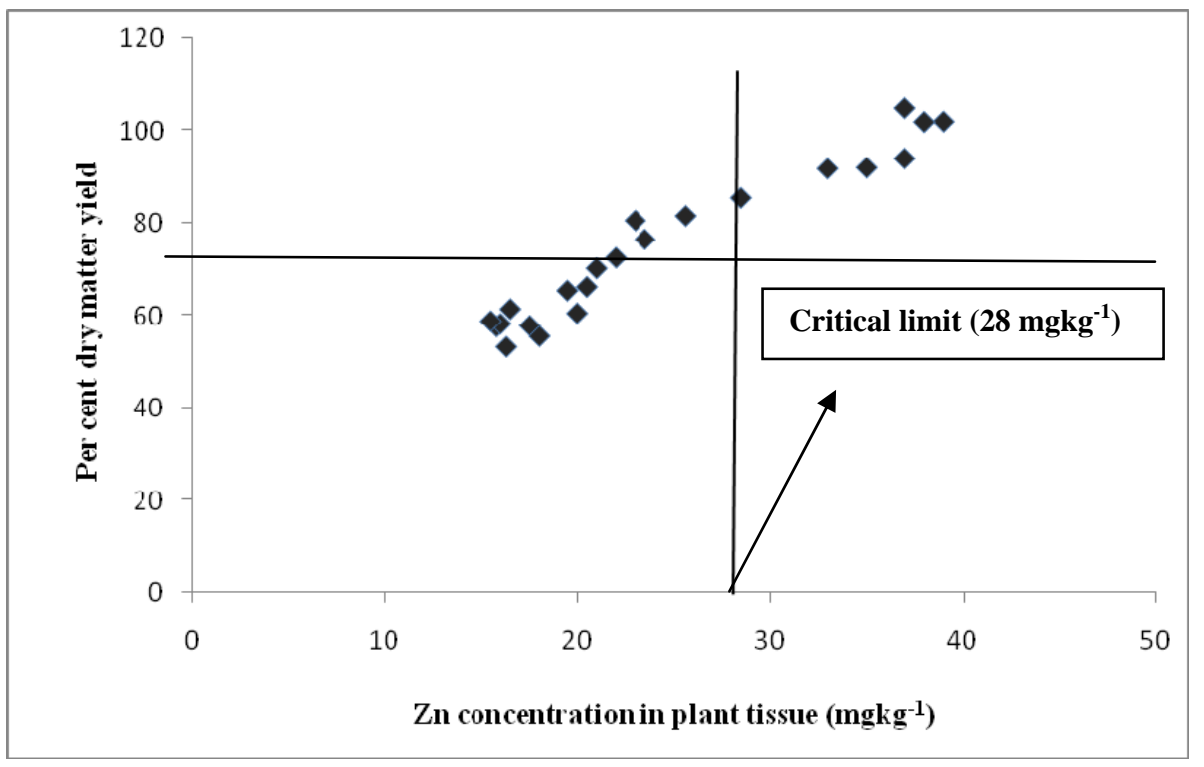

Figure 2. Scatter diagram of third leaf Zn Vs. percent dry matter yield of rice grown in soils of alluvial zone of West Bengal. 